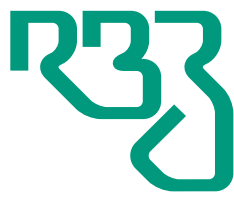

\section{Revista} Brasileira de Zootecnia

Brazilian Journal of Animal Science ISSN 1806-9290 www.rbz.org.br

\title{
Effects of long-term controlled internal drug release reuse on reproductive performance, hormone profiles, and economic profit of sheep
}

\author{
Ayman Abdel-Aziz Swelum ${ }^{1,2 *}$ (iD, Islam M. Saadeldin ${ }^{1,3}$ (iD), \\ Abdullah F. Moumen ${ }^{1}$ (iD, Mohamed Ali $^{4}$ (iD, Hani Ba-Awadh ${ }^{1}$ (iD), \\ Abdullah N. Alowaimer ${ }^{1}$ (iD) \\ ${ }^{1}$ King Saud University, College of Food and Agriculture Sciences, Department of Animal \\ Production, Riyadh, Saudi Arabia. \\ ${ }^{2}$ Zagazig University, Faculty of Veterinary Medicine, Department of Theriogenology, \\ Sharkia, Egypt. \\ ${ }^{3}$ Zagazig University, Faculty of Veterinary Medicine, Department of Physiology, Zagazig, Egypt. \\ ${ }^{4}$ Zagazig University, Faculty of Veterinary Medicine, Department of Animal Wealth \\ Development, Sharkia, Egypt.
}

*Corresponding author: aswelum@ksu.edu.sa

Received: April 11, 2018

Accepted: January 29, 2019

How to cite: Swelum, A. A.; Saadeldin, I. M.; Moumen, A. F.; Ali, M.; Ba-Awadh, H. and Alowaimer, A. N. 2019. Effects of long-term controlled internal drug release reuse on reproductive performance, hormone profiles, and economic profit of sheep. Revista Brasileira de Zootecnia 48:e20180085.

https://doi.org/10.1590/rbz4820180085

Copyright: This is an open access article distributed under the terms of the Creative Commons Attribution License

(http://creativecommons.org/licenses/by/4.0/), which permits unrestricted use, distribution, and reproduction in any medium, provided the original work is properly cited.

\begin{abstract}
Fifty-seven multiparous Awassi ewes in the breeding season were used to compare the effects of controlled internal drug release (CIDR) reuse on hormone profiles, reproductive performance, and economic production. Ewes were randomly allotted to one of three CIDR treatments: new (control), once-used, and twice-used; treatment lasted 12 days. Blood samples were collected from all groups at the time of CIDR insertion, three and six days following insertion, at withdrawal time, and at insemination. Serum estradiol (E2) and progesterone (P4) concentrations were measured. Timed insemination was performed $48 \mathrm{~h}$ post CIDR withdrawal in all groups. Pregnancy was diagnosed by ultrasonography at day 23 post insemination. No significant differences were detected among groups in pregnancy rate/ewes in heat, twinning rate, fecundity, abortion rate, and prolificacy. However, estrus detection rate was significantly higher in control (100\%) than in other groups. The P4 concentration was significantly higher in control than in other groups during treatment period; at insemination, $\mathrm{P} 4$ concentration was significantly higher in control than in other groups; at insemination time, E2 concentration was significantly higher in control than in the other groups; and the net profit was higher in once-used than in other groups. One-time reuse of CIDR for the long term (12 days) can synchronize estrus in ewes efficiently with higher net profit than the new or twice-used CIDR.
\end{abstract}

\section{Introduction}

Estrus synchronization enhances reproductive efficiency and allows the selection of parturition times, which improves production efficiency (Whitley and Jackson, 2004). However, sheep producers gradually adopt synchronization protocols because of the difficulties associated with estrus detection. Therefore, several studies have focused on using blind fixed-time insemination after hormonal treatment in sheep (Fukui et al., 1999). The most efficient hormonal treatments in ovine reproduction programs use intravaginal devices (silicone or polyurethane sponges) impregnated with progesterone (P4) or other progestogens (Abecia et al., 2011; Swelum et al., 2014). Although sponges are generally less costly than silicone (Wheaton et al., 1993), their use can result in greater vaginitis and drawstring breakage rates (Romano, 2004). Additionally, changes in vaginal flora associated with sponges can also negatively affect the sexual attraction of ewes in estrus (Gatti and Ungerfeld, 2012). 
Controlled internal drug release (CIDR) is efficient in the synchronization of estrus and improves the reproductive performance of sheep, cows, and camels (Martinez et al., 2002; Swelum and Alowaimer 2015; Swelum et al., 2015a). It can release limited concentrations of P4 for a longer time than is recommended for synchronization. The device (1.9 g of P4) contains P4 after its use in cattle, with the amount dependent on the duration of insertion (Van Cleeff et al., 1992). There is evidence of a relationship among P4 concentrations during treatments, ovarian follicular turnover, and fertility in sheep. Reused CIDR can release sufficient P4 concentrations to allow adequate blockage of luteinizing hormone, maintaining steroid concentrations well enough to assure good quality of ovulated oocytes (Pinna et al., 2012).

Therefore, discarding CIDR after use can be an economic loss, because it has residual P4. Reusing CIDR decreases environmental contamination because of the lower amount of hormone remaining in the device, and decreases costs, because each device is used more than once. For this reason, some researchers have evaluated the reuse of CIDR for up to two to three times to reduce costs without altering reproductive performance of ewes (Güngör et al., 2009; Ungerfeld, 2009; Vilariño et al., 2013; Swelum et al., 2015b), cows (Colazo et al., 2004), and goats (Oliveira et al., 2001; Vilariño et al., 2011; Souza-Fabjan et al., 2014). All these studies substantiate our hypothesis that CIDR reuse can decrease production costs and increase net profit without adverse effect on the reproductive performance of sheep.

Although the main aim of CIDR reuse is to reduce costs, an economic evaluation of using previously used CIDR for the long term (12 days) has never been studied in sheep. Therefore, the objective of this study was to compare the effects of CIDR reuse up to two times for long-term synchronization of estrus in multiparous ewes on reproductive performance, hormone profiles, and economic profit.

\section{Material and Methods}

Fifty-seven multiparous Awassi ewes and 10 proven fertile rams aged 3-5 years, with a mean body condition score 3 during the winter season, were used in this study. The ewes were group-housed in yards under a roof in an open-sided barn. During the study, daily temperature, relative humidity, and rainfall ranges were $13.5-21.6^{\circ} \mathrm{C}, 24-43 \%$, and $1.6-24.3 \mathrm{~mm} / \mathrm{month}$, respectively. Ewes were fed

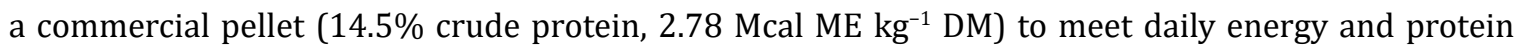
requirements. Before starting our trial, all ewes were examined using ultrasonography to confirm absence of any reproductive pathology or pregnancy. Additionally, rams were subjected to a breeding soundness evaluation, including semen analysis using computer-assisted semen analysis. All animals were healthy and free from the main infectious diseases.

Controlled internal drug release (EAZI-breed ${ }^{T M}$ CIDR $^{\circledR}$, Pfizer Animal Health, New Zealand) constructed with a silicone elastomer impregnated with $0.3 \mathrm{~g}$ natural $\mathrm{P} 4$ was used to synchronize estrus. Ewes were randomly allotted into one of the following treatments: new CIDR, once-used CIDR, or twice-used CIDR to form three different groups as following: control $(n=20)$, once-used $(n=19)$, and twice-used $(\mathrm{n}=18$ ). The used CIDR was thoroughly cleaned and sterilized with alcohol before reusing. All ewes were injected with $300 \mathrm{IU}$ of equine chorionic gonadotropin (eCG; Synchropart ${ }^{\circledR}$ Ceva Sante, Animale, France) at the time of withdrawal. At CIDR withdrawal, the retention, drawstring breakage, and vaginitis rates were calculated for each group (Swelum et al., 2015a). Retention rate was calculated as the percentage of ewes that retained CIDR for 12 days to the total number of ewes. Vaginal discharge rate was calculated as the percentage of ewes that showed vaginal discharges upon removal of CIDR to the total number of ewes that retained the CIDR for 12 days. Drawstring breakage rate was calculated as the percentage of CIDR that firmly adhered and needed an external aid to be removed from the vagina to the total number of ewes that retained CIDR for 12 days. Estrus was detected every $12 \mathrm{~h}$ using a vasectomized ram during the 12-84-h period after CIDR withdrawal. Estrus detection rate and frequency of estrus detection per ewe were calculated. Timed natural mating was performed in a rate of one ram/two ewes for all ewes that retained the CIDR $48 \mathrm{~h}$ after withdrawal in all groups. 
Blood samples were collected via the jugular vein of all ewes into plain vacutainers tubes at the time of CIDR insertion, after three and six days following CIDR insertion, at removal, and at insemination. Serum was separated by centrifugation at 2,000 $\times \mathrm{g}$ for $10 \mathrm{~min}$, transferred into 1.5-mL Eppendorf tubes, and stored at $-20{ }^{\circ} \mathrm{C}$ until analysis. Serum estradiol (E2) and P4 concentrations were measured using commercial ELISA kits (Human Gesellschaft fur Biochemica und Diagnostica mbH, Germany). The assays were performed according to manufacturer's instructions, and absorbance readings were taken using an automated spectrophotometer. The analytic sensitivity of the E2 and P4 ELISA tests were $3-6 \mathrm{pg} / \mathrm{mL}$ (range of $0-2000 \mathrm{pg} / \mathrm{mL}$ ) and $0.03-0.07 \mathrm{ng} / \mathrm{mL}$ (range of $0-40 \mathrm{ng} / \mathrm{mL}$ ), respectively. The intra and inter-assay coefficients of variation were 3.32 and $6.58 \%$ for P4 and 11.93 and $18.65 \%$ for E2, respectively.

A multi-frequency $(5.0 / 6.0 / 7.5 / 10.0 \mathrm{MHz})$ linear trans-rectal ultrasonography probe (Model UST-660-7.5, Aloka, Japan) was used to diagnose pregnancy and number of fetuses at day 23 post-insemination. Pregnancy and number of fetuses were confirmed at day 35 using a multi-frequency (2.5/3.75/5.0/6.0 MHz) convex abdominal probe (Model UST-9137C, Aloka, Japan). The sex of fetuses was recorded at lambing. Weight and height of lambs were recorded immediately after delivery. Gestation length was calculated. Total pregnancy rate (pregnant ewes detected by ultrasound/inseminated ewes $\times 100$ ), twinning rate (ewes that lambed twins/pregnant ewes $\times 100$ ), abortion rate (ewes that aborted/pregnant ewes $\times 100$ ), fecundity (newborn lambs/inseminated ewes), and prolificacy (newborn lambs/pregnant ewes) were calculated.

To calculate the economic measures associated with the production process, cost and return parameters were determined. Cost parameters included the total fixed, total variable, and total costs. The total fixed costs included veterinary medicaments, building and equipment depreciation, purchased sheep, labor, water, and electricity and were equal to US\$23.34/group. Total variable costs included the cost of feed and CIDR. The feed cost was US\$ 0.32/ewe/day. Ewes that failed to retain the CIDR were excluded from our trial at time of CIDR withdrawal (day 12 of experiment); ewes that failed to be pregnant at day 35 post insemination (day 49 of experiment) were also excluded from our trial. Pregnant ewes were included in our trial until delivery (day 14+ gestation length). Total feed costs were calculated individually for each ewe according to its status as mentioned before $(0.32 \times$ number of days that this ewe was included in the present experiment). The CIDR cost was calculated individually for each ewe and was equal to actual cost of CIDR (US\$ 5.87)/number of times used. Total cost is the sum of the total fixed and variable costs. Return parameters depended mainly on the number of born lambs (US $\$ 80.00 / \mathrm{lamb}$ ). The net profit equals total return minus total costs.

Comparisons between groups were conducted using SAS (Statistical Analysis System, version 9.2). Analysis of variance (ANOVA) was used to analyze steroid hormone concentrations, frequency of estrus detection/ewe, weight and height of lambs, and gestation length. The remaining parameters were analyzed using Chi square $\left(\chi^{2}\right)$ test. The effect of CIDR reuse, time of blood sample collection, and CIDR reuse $\times$ time interaction were evaluated. A difference was considered significant at $\mathrm{P}<0.05$. Data were expressed as percentages or mean \pm standard error.

\section{Results}

At the time of withdrawal, ewes that failed to retain CIDR were excluded from the analyses. Estrus detection rate and lambs born/ewe in estrus were significantly $(\mathrm{P}<0.05)$ different among groups. Estrus detection rate was significantly $(\mathrm{P}<0.05)$ higher in the control group than in once-used and twice-used groups. However, born lambs/ewe in heat was significantly $(\mathrm{P}<0.05)$ higher in twice-used than in control group (Table 1).

The percentage of ewes exhibiting estrus was significantly $(\mathrm{P}<0.0001)$ affected by time of estrus detection post CIDR withdrawal. The highest percentages of ewes in estrus in all groups were recorded at $48 \mathrm{~h}$. A significantly $(\mathrm{P}<0.05)$ high percentage of ewes in estrus in the control group was recorded at $48 \mathrm{~h}$ after CIDR withdrawal, whereas a significantly $(\mathrm{P}<0.05)$ high percentage of ewes in estrus in 
once-used CIDR group was recorded at $36 \mathrm{~h}$ and $48 \mathrm{~h}$ after CIDR withdrawal. A significantly $(\mathrm{P}<0.05)$ high percentage of ewes in estrus in twice-used CIDR group was recorded at $48 \mathrm{~h}, 60 \mathrm{~h}$ after CIDR withdrawal. The percentage of ewes in estrus in control was significantly $(\mathrm{P}<0.05)$ higher $48 \mathrm{~h}, 60 \mathrm{~h}$, and $84 \mathrm{~h}$ after CIDR withdrawal than that in other groups (Figure 1).

There were no significant differences among the percentages of lambs born single or twins for all groups. Additionally, the percentage of male or female lambs and their weight, height, and gestation length were not significantly different among all groups (Table 2).

The total variable cost, total cost, and return were higher in control, followed by those in the once-used group. The net profit was higher in once-used, followed by that in the control group. The lowest total variable cost, total cost, return, and net profit were recorded in twice-used group. The cost of CIDR per

Table 1 - Effect of controlled internal drug release reuse for the long term (12 days) up to two times on the reproductive parameters of Awassi ewes

\begin{tabular}{|c|c|c|c|c|c|}
\hline \multirow{2}{*}{ Parameter } & \multicolumn{3}{|c|}{ Group } & \multirow{2}{*}{ Probability } & \multirow{2}{*}{$\chi^{2}$ value } \\
\hline & Control & Once-used & Twice-used & & \\
\hline $\mathrm{N}$ & 20 & 19 & 18 & - & - \\
\hline Retention rate (\%) & 95 & 94.7 & 94.4 & 0.9971 & 0.0059 \\
\hline Vaginitis (\%) & 0 & 0 & 0 & - & - \\
\hline Draw-string breakage rate (\%) & 0 & 0 & 0 & - & - \\
\hline Heat detection rate (\%) & $100 \mathrm{a}$ & $66.67 \mathrm{~b}$ & $47.06 \mathrm{~b}$ & 0.0015 & 12.9502 \\
\hline Frequency of heat detection/ewe & $2.42 \pm 0.23$ & $2.67 \pm 022$ & $2.38 \pm 0.30$ & 0.7216 & - \\
\hline Total pregnancy rate (\%) & 52.63 & 44.44 & 35.29 & 0.5792 & 1.0923 \\
\hline Pregnancy rate/ewe in heat (\%) & 52.63 & 66.67 & 75 & 0.5009 & 1.3827 \\
\hline Fertility or lambing rate (\%) & 52.63 & 44.44 & 35.29 & 0.5792 & 1.0923 \\
\hline Prolificacy (\%) & 120 & 137.5 & 133.33 & 0.8488 & 0.3279 \\
\hline Fecundity (\%) & 63.16 & 61.11 & 47.06 & 0.5762 & 1.1025 \\
\hline Born lambs/ewe in heat (\%) & $63.16 \mathrm{~b}$ & $91.67 \mathrm{ab}$ & $100 \mathrm{a}$ & 0.0436 & 6.2634 \\
\hline
\end{tabular}

a,b - Values within the same row with different letters differed $(\mathrm{P}<0.05)$.

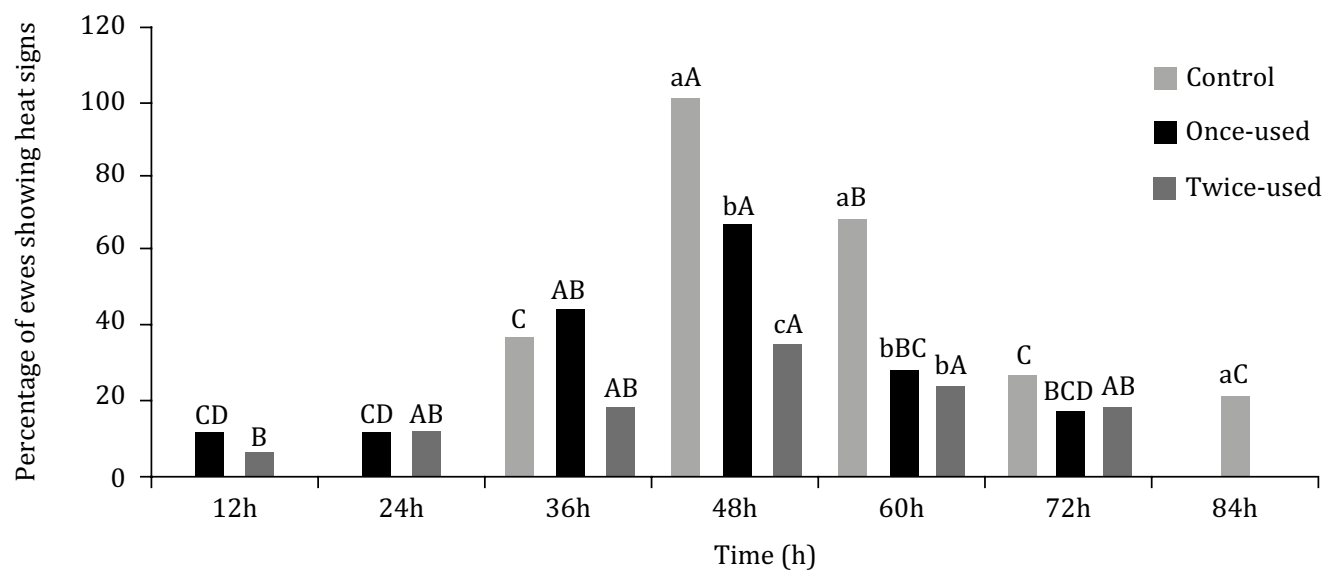

A,B,C - Percentages within the same group with different uppercase letters differed $(\mathrm{P}<0.05)$. $a, b$ - Percentages within the same time of estrus detection with different lowercase letters differed $(\mathrm{P}<0.05)$.

Figure 1 - Effect of controlled internal drug release reuse for the long term (12 days) up to two times on the percentage of Awassi ewes detected in estrus after device removal (h). 
total variable cost, total cost, total return, or net profit were higher in control than in the other groups. The cost of CIDR per net profit was lower in once-used than in the other groups (Table 3).

Generally, reusing CIDR, time of blood collection, and their interaction significantly $(\mathrm{P}<0.05)$ altered serum $\mathrm{P} 4$ concentration. The $\mathrm{P} 4$ in control group was significantly higher than in other groups. The highest concentration of $\mathrm{P} 4$ was observed at CIDR removal compared with the other times. All ewes presented P4 supraluteal concentrations $(>1.0 \mathrm{ng} / \mathrm{mL})$ at CIDR removal. Within a group, $\mathrm{P} 4$ concentration was significantly $(\mathrm{P}<0.05)$ higher at the time of removal than at insemination for all groups. At removal, $\mathrm{P} 4$ concentration was significantly $(\mathrm{P}<0.05)$ higher in control group than in once- and twice-used groups. At insemination, $\mathrm{P} 4$ concentration was significantly $(\mathrm{P}<0.05)$ lower in control and once-used groups than in twice-used group (Figure 2).

The long-term reuse of CIDR significantly $(\mathrm{P}<0.05)$ altered serum E2 concentration, whereas time of blood collection did not significantly alter this parameter. The interaction between CIDR treatment durations and time of blood collection significantly $(\mathrm{P}<0.05)$ altered serum E2 concentration. At insemination time, E2 concentration was significantly $(\mathrm{P}<0.05)$ higher in control, followed by that in twice-used and once-used groups (Figure 3).

Table 2 - Effect of controlled internal drug release reuse for the long term (12 days) up to two times on the percentage of Awassi lambs born single or twin, males or females, their weight, height, and gestation length

\begin{tabular}{|c|c|c|c|c|c|}
\hline \multirow{2}{*}{\multicolumn{2}{|c|}{ Parameter }} & \multicolumn{3}{|c|}{ Group } & \multirow{2}{*}{ Probability } \\
\hline & & Control & Once-used & Twice-used & \\
\hline \multicolumn{2}{|c|}{ Lambs born single (\%) } & 66.67 & 45.45 & 50.00 & 0.5642 \\
\hline \multicolumn{2}{|c|}{ Lambs born twins (\%) } & 33.33 & 54.55 & 50.00 & 0.5642 \\
\hline \multirow{4}{*}{ Male } & $\%$ & 58.33 & 36.36 & 62.50 & 0.4446 \\
\hline & Weight & $3.98 \pm 0.05$ & $3.91 \pm 0.39$ & $3.92 \pm 0.16$ & 0.9751 \\
\hline & Height & $39.50 \pm 0.39$ & $39.25 \pm 0.74$ & $39.80 \pm 0.52$ & 0.8256 \\
\hline & Gestation length & $149.83 \pm 0.84$ & $151.50 \pm 0.25$ & $152.70 \pm 0.44$ & 0.1725 \\
\hline \multirow{4}{*}{ Female } & $\%$ & 41.67 & 63.64 & 37.50 & 0.4446 \\
\hline & Weight & $3.20 \pm 0.36$ & $3.53 \pm 0.19$ & $3.23 \pm 0.50$ & 0.7416 \\
\hline & Height & $35.40 \pm 2.05$ & $38.29 \pm 0.39$ & $36.67 \pm 1.09$ & 0.3343 \\
\hline & Gestation length & $149.60 \pm 1.04$ & $150.86 \pm 0.51$ & $152.33 \pm 0.72$ & 0.191 \\
\hline
\end{tabular}

Table 3 - Effect of controlled internal drug release reuse for the long term (12 days) up to two times on production economic parameters of Awassi sheep

\begin{tabular}{lccc}
\hline & \multicolumn{3}{c}{ Group } \\
\cline { 2 - 4 } Parameter & Control & Once-used & Twice-used \\
\hline Total variable costs (USD) $^{1}$ & 784.95 & 640.05 & 532.53 \\
Total costs (USD) $^{2}$ & 808.28 & 663.39 & 555.86 \\
Return (USD) $^{3}$ & 960.00 & 880.00 & 640.00 \\
Net profit (USD) $^{4}$ & 151.72 & 216.61 & 84.14 \\
CIDR/total variable costs (\%) $_{\text {CIDR/total costs (\%) }}$ & 0.75 & 0.46 & 0.37 \\
CIDR/total return (\%) & 0.73 & 0.44 & 0.35 \\
CIDR/net profit (\%) & 0.61 & 0.33 & 0.31 \\
\hline
\end{tabular}

${ }^{1}$ Total variable costs: sum of costs of feed (US\$ 0.32/ewe/day) and cider (US\$ 5.87, 2.93, and 1.96/ewe in control, once-used, and twice-used groups, respectively).

2 Total costs: sum of variable and fixed costs (costs of building depreciation, labors, animal costs, and equipment depreciation equal US\$23.34/group).

${ }^{3}$ Return: sum of selling price of lambs (US\$ 80.00/lamb).

${ }^{4}$ Net profit $=$ return - total costs. 


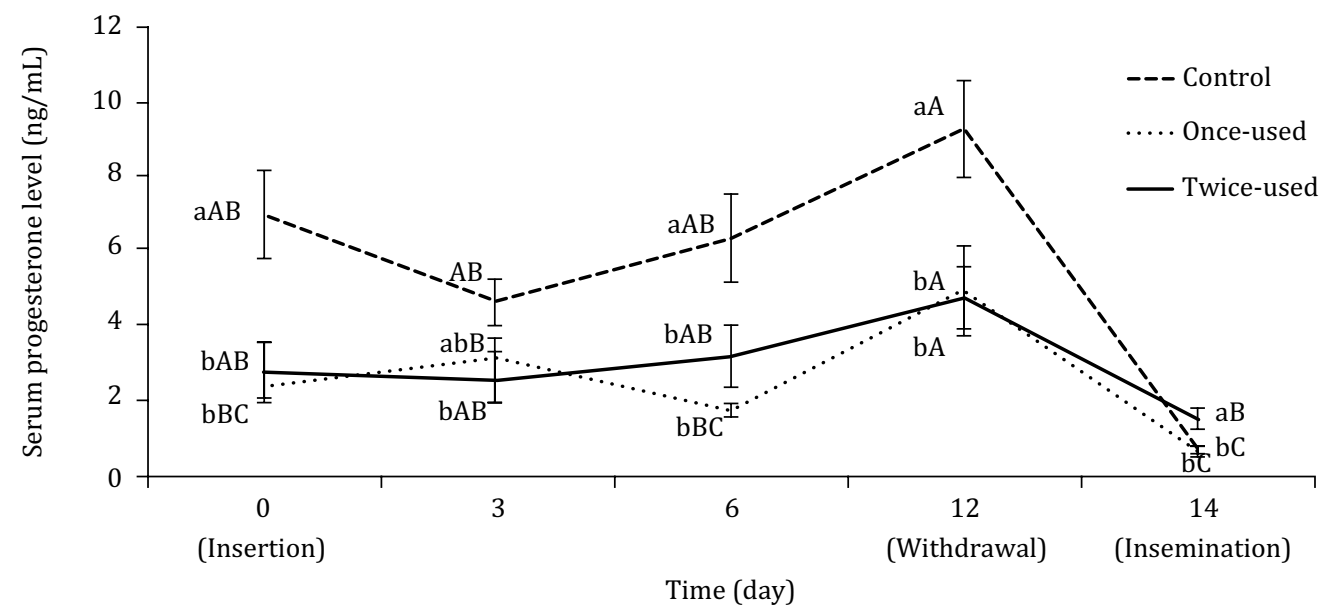

A,B - Mean \pm standard error; different uppercase letters within a group differed; $\mathrm{P}<0.05$. $\mathrm{a}, \mathrm{b}$ - Mean \pm standard error; different lowercase letters within a time differed; $\mathrm{P}<0.05$.

Figure 2 - Effect of controlled internal drug release reuse for the long term (12 days) up to two times and time of blood collection on serum progesterone concentrations (ng/mL) in Awassi ewes.

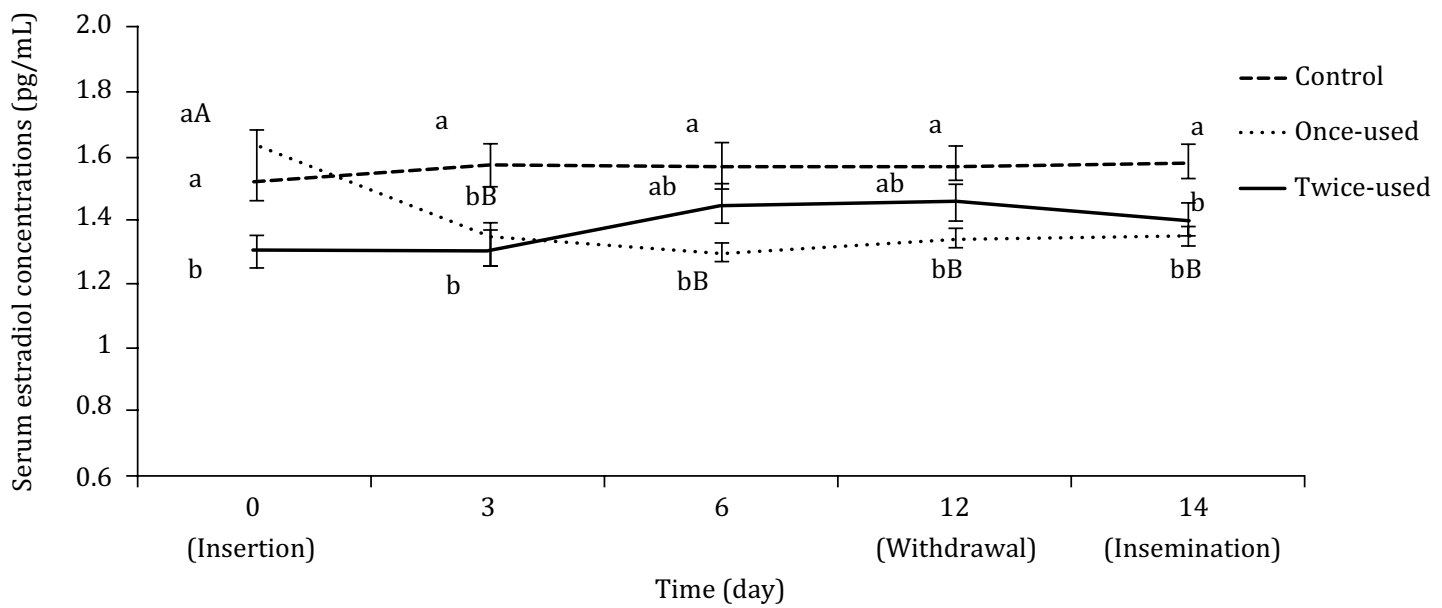

A,B - Mean \pm standard error; different uppercase letters within a group differed; $\mathrm{P}<0.05$.

$\mathrm{a}, \mathrm{b}$ - Mean \pm standard error; different lowercase letters within a time differed; $\mathrm{P}<0.05$.

Figure 3 - Effect of controlled internal drug release reuse the for long term (12 days) up to two times and time of blood collection on serum estradiol concentrations (pg/mL) in Awassi ewes.

\section{Discussion}

Vaginitis and drawstring breakage rates were zero and were not significantly different among groups. This may be attributed to the nature of CIDR, which was made of silicone and did not absorb any vaginal secretions and was well held without adhering firmly to the vaginal wall mucosa. Additionally, following all hygienic precautions, including dry cleaning and disinfection of the perineal region of the ewes, a reduction in the length of device string reduced vaginitis (Vasconcelos et al., 2016). These results were in general agreement with those reported in previous studies (Knights et al., 2001; Dixon et al., 2006; Fleisch et al., 2012).

Estrus detection rate was significantly $(\mathrm{P}<0.05)$ higher in control than in the other two groups. This might have been a result of increasing P4 concentrations from the new CIDR, which caused a stronger 
estrus response and increased the probability of estrus behavior. Additionally, it is well known that P4 concentration increases rapidly in the blood after CIDR insertion and also drops rapidly after CIDR removal, with no cumulative effect (Wheaton et al., 1993; Rubianes et al., 1998). Serum P4 concentrations were significantly lower with CIDR used once or twice, primarily during the first day of treatment because of the large surge in the P4 concentration that is typical when using new CIDR (Wheaton et al., 1993), which nearly doubled the values induced by the reused CIDR. Nevertheless, P4 concentrations during the reused CIDR treatment period were higher than $1 \mathrm{ng} / \mathrm{mL}$ until CIDR withdrawal in all groups. The P4 concentrations induced by the three treatments were effective in blocking estrus behavior, regression of the persistent follicles, inhibition of gonadotropin release from the anterior pituitary, and ovulation until CIDR withdrawal in most animals (Diskin et al., 2002). The P4 concentrations released by the device during the treatments allowed for typical waves of ovarian follicular growth to arise in most animals (Diskin et al., 2002). The drop in P4 concentration following the withdrawal resulted in initiation of ovarian activity via decreasing the negative feedback on pituitary luteinizing hormone secretion and the emergence of a new wave of ovarian follicular development that led to the development of new and healthy follicles from which ovulations occurred (Hashim and Sembiring, 2013; Dias et al., 2015). The reuse of the P4 device did not impact the variables of follicular dynamics and P4 concentration post ovulation but did result in an earlier ovulation after device removal when compared with use of a new P4 device (Dias et al., 2015). In such studies, pre-ovulatory follicles were exposed to sub-luteal concentrations of P4 at the end of the treatment (Menchaca and Rubianes, 2004). Conversely, P4 concentration was lower in goats treated with autoclaved CIDR previously used for six or 12 days than for those treated with new CIDR during both breeding (Souza, 2010) and nonbreeding (Souza et al., 2011) seasons. However, that decrease was not enough to affect reproductive response.

At the time of insemination, $\mathrm{P} 4$ concentration was significantly $(\mathrm{P}<0.05)$ lower in twice-used group than in the two other groups. This may be attributed to the high number of ewes detected in estrus in these two groups, which indicates a very low source of P4 in these groups, whereas other groups might have some ewes with corpus luteum, which elevated the mean P4 concentration in these groups. At insemination, E2 concentration was significantly $(\mathrm{P}<0.05)$ higher in control, followed by that in the once-used group. This may be attributed to the numerically higher twinning rate in these groups. Likewise, Hashim and Sembiring (2013) found that E2 concentration had a positive correlation with the number of large follicles during the estrus cycle; E2 is considered a good marker of follicular quality. Moreover, there are positive correlations among the number of large follicles during the estrus cycle, ovulation rate, number of corpus luteum, and P4 concentration during early pregnancy, which can explain the numerical increase in the pregnancy rate, twinning rate, and fecundity in control and once-used groups.

Our results agree with the results of Güngör et al. (2009), Alvarez et al. (2013), and Swelum et al. (2018b), who concluded that previously used CIDR can be used for the synchronization of estrus in sheep and goats. The percentage of ewes exhibiting estrus and pregnancy rates were not significantly lower with the use of CIDR previously used for 18 days, compared with CIDR that had been used for 12 days (Ungerfeld, 2009). Additionally, CIDR use for six days provided higher return and net profit than that used for nine or 12 days (Swelum et al., 2016; 2018a).

The total pregnancy and fertility rates were numerically, not significantly, decreased in reused treatment groups, which may be related to absence of follicular turnover in all animals and lifespan prolongation of some dominant follicle, provoked by low $\mathrm{P} 4$ concentrations during treatment in these reused CIDR groups (Viñoles et al., 2001; Vilariño et al., 2011). On the other hand, the insertion of a new CIDR caused large surge of P4, followed by follicular turnover in all animals and ovulation occurred from a new follicular wave (Viñoles et al., 2001). Previous studies with ewes reported a decrease in pregnancy rate with the reuse of CIDR for more than 11 days compared with new CIDR (Ungerfeld, 2009; Vilariño et al., 2013). The duration of previous use significantly affects the reproductive parameters and economic profit (Swelum et al., 2018b).

Total variable cost and total cost were higher in control group followed by those in once-used group. This was attributed to the higher fertility rate in these groups, which means that a greater number of 
ewes in our experiment progressed until delivery with additional costs. We excluded all non-pregnant ewes from all groups after pregnancy confirmation at day 35 after insemination. This explains why twice-used group had the lowest total variable cost and total cost. Conversely, the net profit was higher in once-used group, followed by that in control group. This was attributed to the greater number of lambs born in these groups, which compensated for the highest variable and total costs, as well as increased the return and net profit. In once-used group, the cost of CIDR was reduced by half, and the number of born lambs did not significantly differ from the control group (11 and 12 lambs, respectively). Therefore, the net profit was higher in once-used group than in control group, and the cost of CIDR per net profit was lower in once-used group than in control group.

\section{Conclusions}

One-time reuse of controlled internal drug release for the long term (12 days) can synchronize estrus in ewes efficiently with higher net profit than the new or twice-used device.

\section{Acknowledgments}

The authors extend their appreciation to the Deanship of Scientific Research at King Saud University for funding this work through research group no. RG-1438-066. We thank the Deanship of Scientific Research and RSSU at King Saud University for their technical support.

\section{References}

Abecia, J. A.; Forcada, F. and González-Bulnes, A. 2011. Pharmaceutical control of reproduction in sheep and goats. Veterinary Clinics of North America: Food Animal Practice 27:67-79. https://doi.org/10.1016/j.cvfa.2010.10.001

Alvarez, L.; Gamboa, D.; Zarco, L. and Ungerfeld, R. 2013. Response to the buck effect in goats primed with CIDRs, previously used CIDRs, or previously used autoclaved CIDRs during the non-breeding season. Livestock Science 155:459-462. https://doi.org/10.1016/j.livsci.2013.05.010

Colazo, M. G.; Kastelic, J. P.; Whittaker, P. R.; Gavaga, Q. A.; Wilde, R. and Mapletoft, R. J. 2004. Fertility in beef cattle given a new or previously used CIDR insert and estradiol, with or without progesterone. Animal Reproduction Science 81:25-34. https://doi.org/10.1016/j.anireprosci.2003.09.003

Dias, L. M. K.; Paes de Barros, M. B.; Viau, P.; Sales, J. N. S.; Valentim, R.; Santos, F. F.; Cunha Jr., M. C.; Marino, C. T. and Oliveira, C. A. 2015. Effect of a new device for sustained progesterone release on the progesterone concentration, ovarian follicular diameter, time of ovulation and pregnancy rate of ewes. Animal Reproduction Science 155:56-63. https://doi.org/10.1016/j.anireprosci.2015.01.016

Diskin, M. G.; Austin, E. J. and Roche, J. F. 2002. Exogenous hormonal manipulation of ovarian activity in cattle. Domestic Animal Endocrinology 23:211-228. https://doi.org/10.1016/S0739-7240(02)00158-3

Dixon, A. B.; Knights, M.; Pate, J. L.; Lewis, P. E. and Inskeep, E. K. 2006. Reproductive performance of ewes after 5 -day treatment with intravaginal inserts containing progesterone in combination with injection of prostaglandin $F_{2} \alpha$. Reproduction in Domestic Animals 41:142-148. https://doi.org/10.1111/j.1439-0531.2006.00656.x

Fleisch, A.; Werne, S.; Heckendorn, F.; Hartnack, S.; Piechotta, M.; Bollwein, H.; Thun, R. and Janett, F. 2012. Comparison of 6-day progestagen treatment with Chronogest ${ }^{\circledR} \mathrm{CR}$ and Eazi-breed ${ }^{\mathrm{TM}} \mathrm{CIDR}^{\circledR} \mathrm{G}$ intravaginal inserts for estrus synchronization in cyclic ewes. Small Ruminant Research 107:141-146. https://doi.org/10.1016/j.smallrumres.2012.05.014

Fukui, Y.; Ishikawa, D.; Ishida, N.; Okada, M.; Itagaki, R. and Ogiso, T. 1999. Comparison of fertility of estrous synchronized ewes with four different intravaginal devices during the breeding season. Journal of Reproduction and Development 45:337-343. https://doi.org/10.1262/jrd.45.337

Gatti, M. and Ungerfeld, R. 2012. Intravaginal sponges to synchronize estrus decrease sexual attractiveness in ewes. Theriogenology 78:1796-1799. https://doi.org/10.1016/j.theriogenology.2012.07.001

Güngör, O.; Ozyurtlu, N.; Pancarci, S. M.; Kaya, M.; Zonturlu, A. K.; Oral, H.; Cetin, Y. and Polat, B. 2009. Estrous synchronization with used CIDR-G devices in ewes during non-breeding season. Kafkas Üniversitesi Veteriner Fakültesi Dergisi 15:779-783.

Hashim, N. H. and Sembiring, M. 2013. Time of PMSG administration: Effect on progesterone and estradiol concentration in synchronized ewes. Biomedical Research 24.

Knights, M.; Maze, T. D.; Bridges, P. J.; Lewis, P. E. and Inskeep, E. K. 2001. Short-term treatment with a controlled internal drug releasing (CIDR) device and FSH to induce fertile estrus and increase prolificacy in anestrous ewes. Theriogenology 55:1181-1191. https://doi.org/10.1016/S0093-691X(01)00476-9

R. Bras. Zootec., 48:e20180085, 2019 
Martinez, M. F.; Kastelic, J. P.; Adams, G. P.; Cook, B.; Olson, W. O. and Mapletoft, R. J. 2002. The use of progestins in regimens for fixed-time artificial insemination in beef cattle. Theriogenology 57:1049-1059. https://doi.org/10.1016/S0093-691X(01)00682-3

Menchaca, A. and Rubianes, E. 2004. New treatments associated with timed artificial insemination in small ruminants. Reproduction, Fertility and Development 16:403-413.

Oliveira, M. A. L.; Guido, S. I. and Lima, P. F. 2001. Comparison of different protocols used to induce and synchronize estrus cycle of Saanen goats. Small Ruminant Research 40:149-153. https://doi.org/10.1016/S0921-4488(00)00222-4

Pinna, A. E.; Brandão, F. Z.; Cavalcanti, A. S.; Borges, A. M.; Souza, J. M. G. and Fonseca, J. F. 2012. Reproductive parameters of Santa Inês ewes submitted to short-term treatment with re-used progesterone devices. Arquivo Brasileiro de Medicina Veterinária e Zootecnia 64:333-340. https://doi.org/10.1590/S0102-09352012000200012

Romano, J. E. 2004. Synchronization of estrus using CIDR, FGA or MAP intravaginal pessaries during the breeding season in Nubian goats. Small Ruminant Research 55:15-19. https://doi.org/10.1016/j.smallrumres.2003.10.015

Rubianes, E.; De Castro, T. and Kmaid, S. 1998. Estrous response after a short progesterone priming in seasonally anestrous goats. Theriogenology 49:356. https://doi.org/10.1016/S0093-691X(98)90709-9

Souza, J. M. G. 2010. Reutilização de dispositivos intravaginais de progesterona autoclavados para a indução e sincronização de estro em cabras da raça Toggenburg. Dissertação (M.Sc.). Universidade Federal de Viçosa, Viçosa, MG, Brasil.

Souza, J. M. G.; Torres, C. A. A.; Maia, A. L. R. S.; Brandão, F. Z.; Bruschi, J. H.; Viana, J. H. M.; Oba, E. and Fonseca, J. F. 2011. Autoclaved, previously used intravaginal progesterone devices induces estrus and ovulation in anestrous Toggenburg goats. Animal Reproduction Science 129:50-55. https://doi.org/10.1016/j.anireprosci.2011.09.012

Souza-Fabjan, J. M. G.; Torres, C. A. A.; Maia, A. L. R. S.; Brandão, F. Z.; Oba, E.; Bertoldo, M. J. and Fonseca, J. F. 2014. Re-used progesterone devices efficiently synchronise oestrus and ovulation after autoclaving process in Toggenburg goats during the breeding season. Animal Production Science 55:818-822. https://doi.org/10.1071/AN14056

Swelum, A. A. and Alowaimer, A. N. 2015. The efficacy of controlled internal drug release (CIDR) in synchronizing the follicular wave in dromedary camels (Camelus dromedarius) during the breeding season. Theriogenology 84:1542-1548. https://doi.org/10.1016/j.theriogenology.2015.08.003

Swelum, A. A.; Alowaimer, A. N. and Abouheif, M. A. 2015a. Use of fluorogestone acetate sponges or controlled internal drug release for estrus synchronization in ewes: Effects of hormonal profiles and reproductive performance. Theriogenology 84:498-503. https://doi.org/10.1016/j.theriogenology.2015.03.018

Swelum, A.; Alowaimer, A. and Abouheif, M. 2014. 18 Comparison between the efficiency of 30-mg flurogestone acetate intravaginal sponge (FGA-30) and controlled internal drug release (CIDR) to synchronize oestrus in ewes. Reproduction, Fertility and Development 27:101-102. https://doi.org/10.1071/RDv27n1Ab18

Swelum, A.; Mouamen, A. and Alowaimer, A. 2015b. 13 Effect of 6 times reusing of controlled internal drug release (CIDR) for short term ( 6 days) on progesterone level and reproductive performance of awassi ewes. Reproduction, Fertility and Development 28:136-136. https://doi.org/10.1071/RDv28n2Ab13

Swelum, A.; Moumen, A. and Alowaimer, A. 2016. 23 The effect of withdrawal timing of controlled internal drug release (CIDR) on ewe reproductive performance. Reproduction, Fertility and Development 29:119-119. https://doi.org/10.1071/RDv29n1Ab23

Swelum, A. A.; Saadeldin, I. M.; Moumen, A. F.; Ali, M. A. and Alowaimer, A. N. 2018a. Efficacy of controlled internal drug release (CIDR) treatment durations on the reproductive performance, hormone profiles, and economic profit of Awassi ewes. Small Ruminant Research 166:47-52. https://doi.org/10.1016/j.smallrumres.2018.07.018

Swelum, A. A.; Saadeldin, I. M.; Moumen, A. F.; Ali, M. A.; Ba-Awadh, H. and Alowaimer, A. N. 2018b. Efficacy of using previously used controlled internal drug release (CIDR) insert on the reproductive performance, hormone profiles and economic measures of sheep. Reproduction Domestic Animal 53:1114-1122. https://doi.org/10.1111/rda.13212

Ungerfeld, R. 2009. The induction of oestrus in ewes during the non-breeding season using pre-used CIDRs and oestradiol-17 $\beta$ treatment. Small Ruminant Research 84:129-131. https://doi.org/10.1016/j.smallrumres.2009.06.011

Van Cleeff, J.; Lucy, M. C.; Wilcox, C. J. and Thatcher, W. W. 1992. Plasma and milk progesterone and plasma LH in ovariectomized lactating cows treated with new or used controlled internal drug release devices. Animal Reproduction Science 27:91-106. https://doi.org/10.1016/0378-4320(92)90049-J

Vasconcelos, C. O. P.; Brandão, F. Z.; Martins, G.; Penna, B.; Souza-Fabjan, J. M. G. and Lilenbaum, W. 2016. Qualitative and quantitative analysis of bacteria from vaginitis associated with intravaginal implants in ewes following estrus synchronization. Ciência Rural 46:632-636. https://doi.org/10.1590/0103-8478cr20150365

Vilariño, M.; Rubianes, E. and Menchaca, A. 2011. Re-use of intravaginal progesterone devices associated with the Short-term Protocol for timed artificial insemination in goats. Theriogenology 75:1195-1200. https://doi.org/10.1016/j.theriogenology.2010.11.030

Vilariño, M.; Rubianes, E. and Menchaca, A. 2013. Ovarian responses and pregnancy rate with previously used intravaginal progesterone releasing devices for fixed-time artificial insemination in sheep. Theriogenology 79:206-210 https://doi.org/10.1016/j.theriogenology.2012.10.007

R. Bras. Zootec., 48:e20180085, 2019 
Viñoles, C.; Forsberg, M.; Banchero, G. and Rubianes, E. 2001. Effect of long-term and short-term progestagen treatment on follicular development and pregnancy rate in cyclic ewes. Theriogenology 55:993-1004. https://doi.org/10.1016/S0093-691X(01)00460-5

Wheaton, J. E.; Carlson, K. M.; Windels, H. F. and Johnston, L. J. 1993. CIDR: A new progesterone-releasing intravaginal device for induction of estrus and cycle control in sheep and goats. Animal Reproduction Science 33:127-141.

Whitley, N. C. and Jackson, D. 2004. An update on estrus synchronization in goats: a minor species. Journal of Animal Science 82:E270-E276. 